\title{
ANALYSES OF COMPETENCIAS FORMATION AS THE KEY FACTOR FOR SUCCESSFUL EMPLOYMENT OF UNIVERSITY GRADUATES
}

\author{
ANÁLISIS DE LA FORMACIÓN DE COMPETENCIAS COMO \\ FACTOR CLAVE PARA EL EMPLEO EXITOSO DE GRADUADOS \\ UNIVERSITARIOS
}

\author{
A.A. Boldyrikhin \\ Irina Shilova
}

\begin{abstract}
The article deals with issues related to the problems of identifying competences demanded on the labor market, examines the regional aspects of assessing the importance of competences by employers in Russia and Kazakhstan. The competence demanded by the regional labor market have been analyzed, approaches to the formation of effective methods of interaction between universities and the labor market to improve the quality of education have been grounded. The article concerns the modern scientific approaches to identifying key competences. The paper studies approaches to the development of methodological tools that provide multi-criteria assessment (diagnostics) of the activities of educational institutions. Dynamic changes in the labor market, caused by the development of information technologies, lead to the fact that universities offer educational programs that do not meet the latest trends. The article discusses on of the ways to solve this problem by means of competence centers created on the basis of universities.
\end{abstract}

Key words: Competence center, key skills, professional standards, competence map internationalization of education, competence approach in education, typology of key competences, key competences, competence assessment criteria

\section{RESUMEN}

El artículo trata temas relacionados con los problemas de identificación de competencias demandadas en el mercado laboral, examina los aspectos regionales de evaluar la importancia de las competencias por parte de los empleadores en Rusia y Kazajstán. Se analizó la competencia exigida por el mercado laboral regional, se basaron los enfoques para la formación de métodos efectivos de interacción entre las universidades y el mercado laboral para mejorar la calidad de la educación. El artículo se refiere a los enfoques científicos modernos para identificar las competencias clave. El documento estudia los enfoques para el desarrollo de herramientas metodológicas que proporcionan una evaluación de criterios múltiples (diagnóstico) de las actividades de las instituciones educativas. Los cambios dinámicos en el mercado laboral, causados por el desarrollo de tecnologías de la información, conducen al hecho de que las universidades ofrecen programas educativos que no cumplen con las últimas tendencias. El artículo analiza las formas de resolver este problema mediante centros de competencia creados a partir de universidades. 
Palabras clave: Centro de competencias, habilidades clave, estándares profesionales, mapa de competencias internacionalización de la educación, enfoque de competencias en educación, competencias clave, criterios de evaluación de competencias.

\section{INTRODUCTION}

Modern economic development is characterized by the transition of leading countries to a new stage of formation of innovative society - the construction of an economy based on knowledge. High qualification, unique skills and abilities, ability to adapt them to constantly changing activity conditions become the main factor not only for production, but also for the future development of the country as a whole.

One of the major problems of higher education is the gap obtained in the process of learning knowledge and ability to implement it in practice, acute shortage of qualified and competent personnel, and obsolescence of information faster than the cycle of learning at the University. Modern society is characterized by very rapid obsolescence of information, the consequence of which is the depreciation of specialized professional knowledge. . The lack of effective use of human capital is largely due to the lack of coordination between the labour and education markets. In order to overcome this imbalance a system to monitor the employers' satisfaction of graduates will be introduced according to the "National project Education" (realization period 01.01 01.01.2019 - 31.12.2024). It is suggested this new monitoring system would allow understanding how satisfied the employer is with the graduate's education. It will also make clear how the educational programs correspond to the regional labor markets and economy structure, also taking into account the self-employment sector. In these conditions, the competence approach in higher education becomes the only possible form of teaching. Within this approach competences are considered as new formations that are created and developed on the basis of knowledge, skills, and experience, but are not reduced to a simple sum of these skills, qualities and abilities. They allow an individual to successfully and constantly perform actions, functions, tasks, broadly or similarly designated, and can be improved and expanded through training.

In the system of higher education in Europe which based on the principles of Bologna Declaration, the task of training competitive and competent specialists is extremely urgent taking into account the trends of economic development. The main objective of the Bologna Agreement (1999) is to improve the efficiency and productivity of higher education in Europe, which is similar for the situation developing in Russian education. As a result, one of the most important criteria for assessing the activities of the University, both in Russia and abroad, is the level of demand for graduates in the labor market.

OECD member countries understand the term "competences" as skills, qualities and abilities that enable an individual to successfully and continuously perform actions, functions and tasks, broadly or similarly designated, and that can be improved and expanded through training. In Europe, the understanding of the need to create a list of promising competences that employees should possess arose in the early 2000s. In recent years, cooperation between the state and employers in the field of education and training in Europe has played a decisive role in the formation of the European higher education area (EHEA).

The development of professional education and training programs took place simultaneously within the framework of the activities of the European Union (EU) and the Organization for 
Economic Cooperation and Development (OECD). On November 12, 2002, the EU Council for Education, Youth and Culture adopted a resolution on strengthening cooperation in the field of professional education and training (Kekkonen A.L, Sigova S.V., 2011). Cooperation involves the prediction of demand for professional competences of workers and graduates. This process was called the "Copenhagen process" the activities of which are still ongoing. One of the directions of this program development was assistance in creating the list of demanded competences and qualifications at the branch level with participation of state, educational institutions and employers. The internationalization of education is actualized in the study of competences which affect not only theoretical aspects, but also have an applied impact.

At present Russia is developing a methodology for the formation of labor resources balance, the main document in this sphere is "Order of the Ministry of Labor and Social Protection of the Russian Federation on the 15 of April 2019 г. N 248н " Approval of the methodology for developing a forecast of the balance of labor resources ". There was created a mechanism of interaction between the state and educational institutions to predict the needs of the economy in qualified personnel, which is implemented through the approval of annual admission numbers for the education system. The forecast of admission control figures is carried out within the framework of the quantitative forecasting system and is conducted by both public and private organizations. Then the matrices of professional and qualification compliance by education levels are formed, comprising the types of economic activity with extended groups of specialties. Thus, the interaction between the state and the professional education system is developing rapidly. Together with the development of professional standards and new Federal Educational Standards, it becomes possible to predict and regulate the emergence of new competences demanded by the labor market with the participation of employers.

The so-called "quality of graduates" is an important criterion for assessing the activities of modern universities, which can be interpreted as the ability of a graduate to find employment. In the academic literature the quality of graduates is most often evaluated in terms of the labor market demand. At the same time, a significant number of studies and monitoring aimed at assessing market demand study mainly formalized indicators of graduates' employment: work in the diplomaspecific area, position, salary, etc. Meanwhile, continuous and rapid changes (technologies, markets, risks) in the economy create objective difficulties in the exact correspondence of professional training to the structure of jobs and specialties. Formal criteria of candidate's eligibility for a vacant position are often supplemented with requirements to the general professional and supraprofessional (metaprofessional) competences (Bochkareva R. A., 2010).

The most important thing for employers is candidates' ability to process information, as well as various behavioral skills that allow them to successfully interact with other people and respond flexibly to changes in the environment. The paradigm of innovative economy requires the transformation of social positioning foundations "from material capital and once mastered profession to social capital and the ability to adapt" (Kekkonen A.L, Sigova S.V., 2011).

Talent, creativity and initiative of a person become the most important resources of economic and social development, alongside with the education of employees that meet the requirement of continuous updating of knowledge, skills and abilities. This is the most important task of modern education system. In these conditions, of course, the requirements for the results of educational activities are changing and the relevance of the formation of competences corresponding to the new demands of the labor market is increasing.

Studies show that about one out of three employees do not use their knowledge and professional skills (Bochkareva R. A., 2010). Therefore, on the one hand, there is a need for active investment 
in development of human capital quality to preserve Russia's competitive advantage. On the other hand, when employed, graduates often find out that their acquired competences are not useful while there is a shortage of other professional skills at the same time.

To overcome this contradiction by means of updating the content of professional education, there is a need for information about what competences are demanded by the employers in the labor market in the current and future periods; what graduates should know and be able to do; what practical experience they should have to skillfully solve the professional tasks.

The research of labor market needs conducted By Y. M. Roshchina and I. S. Russkikh shows that Russian employers appreciate the basic professional skills of University graduates but are significantly less satisfied with the level of development of key competences. A. A. Malysheva and I. V. Nevraeva give a short list of key competences expected from young professionals: willingness to self-develop, communication skills, the ability to get results, acceptance of new (Bochkareva R. A., 2010). A. I. Podolsky, based on the results of company executives' survey, among the competences that are in great demand by Russian management, names the ability to make nonstandard decisions, work with people, solve problems, openness to new ideas, ability to plan activities, emotional stability, ability to avoid conflict situations. The study of "Skolkovo" Moscow Management School identifies a number of professional skills and abilities, which can also be considered as key competences: system thinking (ability to work with complex systems), intersectoral communication, project and process management, programming (including work with artificial intelligence), customer orientation, multilingualism and multiculturalism, working in teams, working in uncertainty mode, creativity / aesthetics, lean production (Bochkareva R. A., 2010).

Since the system of higher education is an important component of the overall socio-economic system of the region, it must have a direct impact on the labor market of the region and contribute to the development of the regional economy. Fast response to changes in the requirements of the regional labor market allows the education system to meet the needs of the regional economy in the renewal and replenishment of personnel, to produce required professionals who can work productively in a competitive labor market. The strategic approach to the preparation of competitive graduates provides a comprehensive study of the factors that influence the competitive qualities formation of an individual (graduate) to possess the optimal competences combination that allow effective work in the organization.

The lack of a stable relationship between higher education and the labor market leads to a significant misbalance between the requirements for graduates by employers and the level of students' training in educational institutions. The relationship between employers and higher education institutions' graduates involves the satisfaction of mutual interests; we have to keep in mind that all participants in this process pursue their own interests and goals, but at the same time they must actively interact and have to meet the requirements of the other side. A necessary condition for ensuring high quality of higher education is the inclusion of representatives of the real sector of the economy, such as employers' associations, in the goals setting process, educational process implementation and evaluation of its results (Sigova et.al., 2013).

In the rapidly changing conditions of the modern labor market the requirements of employers in the area of graduates' professional competences are becoming increasingly high as a result of globalization, increasing competition, features of corporate culture and image of enterprises. In these conditions graduates need to take into account the trends in the market demand for specific qualifications and requirements of employers, actively work on the formation and improvement of 
personal and professional qualities in order to expand the opportunities for obtaining a prestigious job after graduation.

At the regional level, the identification of required competences involves the implementation of the following actions:

1. Consultations with employers, trade unions, expert groups on future professional needs, talks with representatives of public organizations, government departments, industrial development organizations, education bodies, social organizations and Chambers of Commerce.

2. Student surveys.

3. Surveys on the expected needs of local employers.

4. Assessment of the graduates' competences quality within educational programs.

5. Evaluation of the learning outcomes effectiveness.

\section{Methodology}

Questions of professional competence are studied in the works of Russian and foreign researchers V. I. Baydenko, A. G. Bermus, E. F. Zeer, I. A. Zimnaya, A. G. Sergeyev, G. K. Selevko, A.V. Khutorskaya, I. A. Zimnaya, O. V. Churakova, G. S. Trofimova, A.V. Khutorsky, F. Weinert, J. A. Soland, L. Hamilton, B. Stecher et al., and are all devoted to the scientific problems of competence formation.

There are two different approaches in the Russian scientific school. In the first case, competence is identified with competences (V. A. Bolotov, V. S. Lednev, M. V. Ryzhakov, V. V. Serikov, etc.), while in the second approach it is viewed as a fundamental distinction is introduced (E. F. Zeer, I. A. Zimnaya, A.V. Khutorskoy, S. E. Shishov, etc.). Thus, A.V. Khutorskoy understands competence as "some alienated, predetermined requirement for the educational preparation of a student, and competence as his personal quality (characteristic) that has already taken place" (Eremina A.V., Zoroastrova I.V., Suchkova E.O., 2015). Competence includes a set of correlated personality qualities (knowledge, skills and methods of activity), that are set in relation to a certain range of subjects and processes and are necessary for high-quality productive activities related to them. Whereas competence is the possession of the corresponding competence of a person, including his personal attitude to it and the subject of activity. I. A. Winter considers competences as integrated characteristics of personality qualities, allowing carrying out activities in accordance with professional and social requirements, as well as personal expectations (Eremina et al., 2015). Competences are substantial personal qualities that combine theoretical and empirical knowledge presented in the form of concepts, principles, laws, practice-oriented provisions and procedural (methodical) prescriptions. Multifunctional, interdisciplinary and transdisciplinary competences form the basic competences. These include: general scientific, socio-economic, civil law, information and communication, polytechnic, general professional competences.

According to E. F. Zeer, competences are generalized ways of actions that ensure productive performance of professional activity. This is the ability of a person to put into practice their competence (Zaeer E., Zavodchikov D., 2011). The core of competence is activity abilities, which are sets of action ways, which means that the operational and technological component determines the essence of competences. Since the implementation of competences occurs in the process of performing a variety of activities to solve theoretical and practical problems, the structure of competences also includes motivational, volitional and emotional spheres. An important 
component of competences is experience, which is the integration of individual actions, methods and problem-solving techniques learned by a person into a single whole.

In modern scientific researches the ambiguity of approaches to outlining key competences is observed. German psychologist and teacher F. Weinert mentions as key ones the possession of oral and written speech in the native language, mathematics, reading and perception of information, foreign languages, skills of using media, learning strategies, social skills, non-standard thinking, the ability to critically evaluate information, self-criticism. According to Weinert, competences are "the available cognitive abilities and skills of an individual to solve certain kinds of problems that an individual can have or master through training, as well as the associated motivational, volitional and social predispositions and abilities that allow the competences to be manifested for successful and responsible problem solving in variable situations" (Eremina et al., 2015). The typology of key competences includes social (the ability to exchange information, communicate, establish and maintain social ties), personal (discipline, motivation, self-awareness, flexibility, etc.), methodological (the ability to develop, choose and apply appropriate strategies for solving problems) and business (knowledge and abilities beyond a certain professional sphere) ones. The concept of F. Weinert was the basis for a number of major international studies, including the Organization for Economic Cooperation and Development (OECD) projects "Definition and selection of competences: theoretical and conceptual studies" (DeSeCo, since 1998) and "Program for International Student Assessment" (PISA, since 2000).

The study Of J. Soland, L. Hamilton and B. Steher devoted to the assessment of key competences of the XXI century, considers the categories of cognitive, personal and personal competences (Eremina et al., 2015).

The group of cognitive competences includes: academic skills (knowledge of basic educational programs, knowledge of foreign languages, etc.), critical thinking (inductive and deductive thinking, analysis, ability to formulate conclusions and assessments), creativity (creative approach to problem solving). Having critical thinking is important for building a successful career because in a competitive economy companies are interested in employees that would be involved in processes of continuous improvement of management, products or services. The study also links critical thinking to other important social outcomes: citizens who are able to think critically are more likely to be self-sufficient and less dependent on government resources. Creativity has a similar effect, being the driving force of innovation and entrepreneurship, so the development of this competence is one of the main focuses within educational programs around the world.

The group of personal competences is formed by: communication and cooperation (the ability to work together, resolve conflicts, negotiate), leadership (includes aspects of communication and cooperation, along with a sense of future vision and competences related to working with people), global consciousness (understanding how events occurring in one part of the world affect people and economy in another part, empathy for people of different cultural traditions).

Intrapersonal competences are: the ability to learn ("metacognition", the ability of the student to independently determine the problem or task, to understand how and in what ways to resolve it), internal motivation (interest or desire to engage in certain activities that motivate for achieving specific goals), endurance (the ability to set long-term goals and achieve them, to complete longterm, multi-stage projects).

In the Russian scientific literature, during the formation of the concept, different authors called the key competences differently: general, basic, trans-subject, meta-subject, metaprofessional and systematic. The FSES3+ (Federal State Educational Standard 3+) introduces the name "universal". 
For example, E. F. Zeer mentions that "competences of a wide range of uses, which have certain universality, are called key or universal". According to this researcher, universal competences determine the implementation of special competences and specific competences (Zaeer et al., 2011). The same core competences ensure the productivity of different activities. Competence cannot be isolated from the specific conditions of its implementation.

1. A common fact about all definitions of universal (key) competences is its understanding as the ability of an individual to cope with a variety of social and professional tasks, which provides a young specialist with dynamic professionalism, which are successful adaptation and mobility. However, this understanding does little to operationalize the concept, namely, it does not allow the use of measurement (diagnostic procedures) and evaluation (the ratio of the measurement result to the standard or sample). In its framework, only the analysis of the problem field of professional activity can be defined, which can serve as the basis for determining the composition of competences that could be subject to future evaluation.

2. Competence is also understood as a set of knowledge, skills and abilities that are necessary to perform a particular job and ensure the implementation of certain professional functions. Cognitive and affective skills must interact (along with motivation, emotional aspects and relevant values). The harmonizing interaction of this set leads to a comprehensive understanding of competence.

This methodological position makes it possible to describe the competence through the functional analysis of the activity as a set of the above mentioned elements, which allows formulating the names of each competence and describing them in a meaningful way. E. F. Zeer distinguishes two groups of universal competences.

Table 1:Classification of universal competences

\begin{tabular}{|c|c|}
\hline Instrumental & Socio-personal \\
\hline $\begin{array}{l}\text { 1. Ability to forecast. } \\
\text { 2. Spatial imagination and combinatorial } \\
\text { abilities. } \\
\text { 3. Communication. } \\
\text { 4. Work with technical documentation. } \\
\text { 5. Innovation and rationalization. } \\
\text { 6. Technological discipline. } \\
\text { 7. Work organization of others and quality } \\
\text { control. } \\
\text { 8. Office equipment usage. }\end{array}$ & $\begin{array}{l}\text { 1. Technical intelligence. } \\
\text { 2. Efficiency. } \\
\text { 3. Emergency readiness (vigilance). } \\
\text { 4. Organization of personal work } \\
\text { 5. Responsible attitude to profession/labor. } \\
\text { 6. Observation and the ability to estimate. } \\
\text { 7. Professional discipline. } \\
\text { 8. Ability to professional learning and self- } \\
\text { learning. } \\
\text { 9. Team work. } \\
\text { 10. Sense of duty. } \\
\text { 11. Decision making. } \\
\text { 12. People management. }\end{array}$ \\
\hline
\end{tabular}

Source: Zaeer et al., 2011

According to A.V. Khutorskoy, key competences are meta-subjective and integrative in their nature, as they are derived from different spheres of culture and activity (Eremina et al., 2015). R. A. Bochkareva proposes to group key competences in the form of eight binary groups of competences (Bochkareva R. A., 2010):

1. General professional competence (bachelor) are the competences required by the subject of the labor market to perform labor functions of simple and medium complexity with low responsibility, based on" old " knowledge. 
2. Professional competences (scope model) are higher level competences based on the "modern" knowledge required by the subject of the labor market to perform complex labor functions, characterized by a high degree of responsibility and the presence of a creative component.

3. Research competences (science model) combine competences based on the use and generation of" new " knowledge.

4. Educational competences (model of educational process) assume that the subject has the ability to lifelong learning, ability to self-education and education of others.

5. Social competence reflects the ability of the subject to function effectively in society, adequately showing their personal and work qualities.

6. Personal competences (personality model) are competences that reflect the natural and acquired characteristics of the subject, manifested in his life, including work.

7. Value-motivational competence, fixing the spiritual and moral component of the personality of the subject, his motives and guidelines.

8. Economic competences represent the competences necessary for the subject of the labor market to participate in socio-economic relations.

On the basis of the above mentioned classification it becomes possible to allocate the main signs of key competences. First, they represent various universal mental means and tools (ways, methods, skills) of achieving the purposes and results that are significant for a person. And secondly, they allow to independently (and in cooperation with others) achieve results in uncertain, problematic situations that do not have a preset of resolution steps (Belenov O.N., Shilova I.V., 2017).

Within the framework of the COMPLETE Project (Establishment of Centers for Competence and Employability Development), funded by Erasmus Plus Program of the EU, Voronezh State University has conducted a survey aimed at identifying competences that are of high demand in the labor market from the point of view of three target groups representatives: employers, graduates and students. The survey was conducted among students and graduates of different faculties of 5 Russian and 3 Kazakhstan universities (participants of the COMPLETE Project), as well as employers in two countries. As the respondents represent different fields of activity, the analysis did not cover the competences related to professional specifics, but only the ones that relate to the key category.

Importance assessment of competences that have the greatest impact on the employment of graduates was carried out using the ordinal scale, which allows identifying the relative differences between the measured characteristics and makes it possible to organize the answers in a hierarchical order.

Taking into account the existing approaches to the typology of key competences (cognitive, personal and intrapersonal), the following groups were identified, each included a set of certain competences (Belenov et al., 2017):

- General professional competence (skills of information search and processing; skills of working with a computer and Internet; high proficiency in conducting business correspondence, making reports and other documents; understanding of enterprise business processes and their relationships; excellent Russian language; knowledge of foreign languages).

- Communication competence (abilities to: negotiate; present the product or service; clearly express ideas; establish contacts within the team; build contacts with contractors (customers, suppliers, etc.) 
- Behavioral characteristics (responsibility, discipline; focus on results; abilities to: meet corporate standards, maintain loyalty to the company; effectively use working time; work in any conditions, under pressure, in a stressful situation; organize the process of work in the organization).

- Skills related to teamwork (abilities to: motivate others to work; take responsibility; motivation to challenge existing ideas and opinions; work in a team and achieve collective goals; correctly defend their position; positive attitude to the environment).

- Analytical competence, ability to self-education and professional growth (includes: quickly learn new knowledge; focus on career growth; analytical thinking; readiness for continuous professional growth; systematic thinking, the ability to calculate the consequences of decisions).

- Innovative competences (vision of new opportunities; generation of new ideas; initiative, independence; ability to abstract, go beyond the situation).

Alongside with the assessment of the importance of competences, the study identified the conditions and opportunities for employment of University graduates, the successful development of their careers, the assessment of employers' expectations for University graduates, the representation of the employment process from the point of view of students and graduates at the regional level.

Non-probability quota sampling techniques was applied in form of quota sampling. The number of students studying at various faculties in educational institutions of Russia and Kazakhstan was used as control category for population (students and graduates). Information collection was carried out using the method of online survey, questionnaires were developed on Google Forms. This method was chosen due to the fact that it allowed carrying out a survey of a large number of respondents in a relatively short time and obtaining data for further analysis in the most convenient form. The final sample include 633 respondents, 499 from Russia and 134 from Kazakhstan.

\section{RESULTS}

As a result of the analysis of competences distribution by levels of significance according to the data of the entire sample (respondents of the Russian Federation and Kazakhstan), a set of actual requirements of employers was formed, including skills from all the selected groups of competences.

The first level of importance for employers is the ability of candidates to search and process information, as well as behavioral skills that allow them to successfully interact with other people, meeting the requirements of the organization with respect to discipline, to respond flexibly to changes in the environment. The results obtained are related to the fact that the paradigm of innovative economy requires transformation of social positioning foundations and strengthening of the importance of ability to socialize and adapt to current conditions in which the most important resources of economic and social development are creativity and initiative of an employee.

In the group of cognitive competences the most popular are system thinking, the ability to calculate the consequences of decisions ("system thinking, the ability to calculate the consequences of decisions"). Of great importance for employers are personal competences that determine the ability to communicate and cooperate. The competences included in this group are located at the first and 
second level in terms of importance ("ability to work in a team", "ability to build contacts with contractors") (Belenov et al., 2017).

In order to identify the country-specific features of the requirements for University graduates, the analysis of the level of importance of competences for employers in Russia and Kazakhstan was carried out. The results indicate a common approach to the factors that ensure the level of demand for graduates in the labor market in both countries, especially affecting general professional and communication competences. The observed differences are due to working conditions: for Russian employers analytical skills are the first priority, whereas for Kazakhstan employers these are the initiative, independence and the ability to quickly learn new knowledge (Gaivoronskaya S.A., Shilova I.V., 2018).

Table 2: Comparative table of competence demand from employers of Russia and Kazakhstan

\begin{tabular}{|c|c|c|c|}
\hline & \multirow{2}{*}{ Match } & \multicolumn{2}{|l|}{ Differences } \\
\hline & & Russia & Kazakhstan \\
\hline Level 1 & $\begin{array}{l}\text { Information retrieval } \\
\text { and processing skills } \\
\text { Ability to negotiate } \\
\text { Responsibility, } \\
\text { discipline. } \\
\text { Ability to work in a } \\
\text { team and achieve } \\
\text { collective goals }\end{array}$ & $\begin{array}{l}\text { Analytical thinking. } \\
\text { Vision of new } \\
\text { opportunities. }\end{array}$ & $\begin{array}{l}\text { The ability to Express your } \\
\text { ideas clearly. } \\
\text { Ability to quickly learn new } \\
\text { knowledge. } \\
\text { Initiative, independence. }\end{array}$ \\
\hline Level 2 & $\begin{array}{l}\text { Understanding the } \\
\text { business processes of } \\
\text { the enterprise and their } \\
\text { relationships. }\end{array}$ & $\begin{array}{l}\text { The ability to express ideas } \\
\text { clearly. } \\
\text { Focus on results. } \\
\text { The ability to build the } \\
\text { work process in the } \\
\text { organization. } \\
\text { Ability to motivate others } \\
\text { to work. } \\
\text { Ability to quickly learn new } \\
\text { knowledge } \\
\text { Initiative } \\
\text { independence. }\end{array}$ & $\begin{array}{l}\text { Ability to establish } \\
\text { contacts in the team. } \\
\text { Ability to work in any } \\
\text { conditions, under pressure, } \\
\text { in a stressful situation. } \\
\text { The ability to take } \\
\text { responsibility. } \\
\text { Systematic thinking, the } \\
\text { ability to calculate the } \\
\text { consequences of decisions. } \\
\text { Ability to generate new } \\
\text { ideas. }\end{array}$ \\
\hline Level 3 & $\begin{array}{l}\text { Ability to present } \\
\text { products and services }\end{array}$ & $\begin{array}{l}\text { Skills of work with } \\
\text { computer and the Internet. } \\
\text { Ability to comply with } \\
\text { corporate standards, } \\
\text { maintain loyalty to the } \\
\text { company. } \\
\text { Ability to work in any } \\
\text { conditions, under pressure, } \\
\text { in a stressful situation. }\end{array}$ & $\begin{array}{l}\text { Foreign languages } \\
\text { knowledge. } \\
\text { Ability to build contacts } \\
\text { with contractors. } \\
\text { Focus on results. } \\
\text { Ability to motivate others } \\
\text { to work. } \\
\text { Analytical thinking. }\end{array}$ \\
\hline
\end{tabular}




\begin{tabular}{|c|c|c|c|}
\hline & & $\begin{array}{l}\text { Responsibility. } \\
\text { Systematic thinking, the } \\
\text { ability to calculate the } \\
\text { consequences of decisions. } \\
\text { Ability to generate new } \\
\text { ideas. }\end{array}$ & $\begin{array}{l}\text { Vision of new } \\
\text { opportunities. }\end{array}$ \\
\hline Level 4 & $\begin{array}{l}\text { Excellent Russian } \\
\text { language command. } \\
\text { Positive attitude to the } \\
\text { surrounding reality. } \\
\text { Readiness for } \\
\text { continuous } \\
\text { professional growth. } \\
\text { The ability to abstract, } \\
\text { to go beyond the } \\
\text { situation. }\end{array}$ & $\begin{array}{l}\text { Ability to build contacts } \\
\text { with contractors. } \\
\text { Ability to effectively use } \\
\text { working time. }\end{array}$ & $\begin{array}{l}\text { Ability to competently } \\
\text { conduct } \\
\text { correspondence, make } \\
\text { reports, reports, other } \\
\text { documents. } \\
\text { Skills of work with } \\
\text { computer and the Internet. } \\
\text { Ability to comply with } \\
\text { corporate standards, } \\
\text { maintain loyalty to the } \\
\text { company. } \\
\text { The ability to build the } \\
\text { process of work in the } \\
\text { organization. } \\
\text { Ability to defend your } \\
\text { position correctly. }\end{array}$ \\
\hline Level 5 & $\begin{array}{l}\text { Motivation to } \\
\text { challenge existing ideas } \\
\text { and opinions. } \\
\text { Focus on career } \\
\text { growth. }\end{array}$ & $\begin{array}{l}\text { Ability to competently } \\
\text { conduct business } \\
\text { correspondence, make } \\
\text { reports, speeches, other } \\
\text { documents. } \\
\text { Ability to establish contacts } \\
\text { in the team. } \\
\text { Ability to defend your } \\
\text { position correctly. }\end{array}$ & $\begin{array}{l}\text { Ability to effectively use } \\
\text { working time. }\end{array}$ \\
\hline
\end{tabular}

Source: Original material

A detailed analysis was conducted to study the situation in the Voronezh regional labor market based on the data acquired from 361 respondents of the Voronezh region, with the following distribution in three target audiences: students (240), graduates (92), employers (29).

1. Characteristics of the employment process from the students and graduates' points of view. Employment issues at the end of higher education process are relevant for the majority of young professionals. More than half of graduates have been looking for or are in search of work, among students the share of those planning to search for work is $80 \%$. A significant number of Voronezh graduates (41.3\% of the respondents in this group) do not currently search for work, which may be due to a more realistic assessment of the situation in the labor market by representatives of this group and understanding of the difficulties of employment compared to students who are still in the process of training and have an abstract idea of their demand as specialists in the real economy sector. 
In the process of job search, representatives of the younger generation use or plan to use various ways to obtain the necessary information and achieve their goals, both "civilized" (recruitment agencies, specialized websites, ads in the media) and informal (help from relatives, friends). Quite a large number of students $(41.5 \%)$ consider the internship to be an effective way of finding a job based on the results of practical training, unlike graduates who really assess the situation: in this group only $4.5 \%$ of respondents hope for help from the University.

During of the survey the importance of criteria that students and graduates are guided by in the process of finding a place of future work was assessed. As it was expected, the most significant indicators for the modern youth are the level of wages and the prospect of professional and career growth (1, 2 and 3 places in importance, respectively). The image of the organization has a certain value (4th place), but obviously is not a criterion that significantly affects the preferences for employment.

The possibility of official employment is not critically important for representatives of this group (5th place), which may well be due to lack of work experience and lack of understanding of the advantages of formal workforce registration in accordance with all the requirements of the Labor Law.

Graduates and students identify two main problems associated with the employment process. These problems are equally significant for representatives of this audience (1st place). In a real market situation, graduates are faced with the lack of a sufficient number of vacancies in their field of activity. This problem is rather due to the imbalance between the requirements of the market and the number of specialists produced by higher education institutions for certain activities. The second problem is connected with the status of graduates - the lack of real work experience. Students and graduates believe that they do not have sufficient knowledge and skills that would allow them to navigate the labor market, which could make the employment process more efficient (3rd place in importance). Lack of practical skills and knowledge in the specialty in the ranking of difficulties associated with job search, are on the 4th and 5th place, respectively.

Young professionals with higher education, faced with the conditions and requirements of the modern labor market, believe that the difficulties in the process of employment and in the future work are associated with the insufficient volume of competences formed during university education (table 1). According to students, the greatest gaps are observed in such competences as "ability to negotiate" and "ability to competently conduct business correspondence" $(47.9 \%$ and $45.4 \%$ of representatives of this group, respectively).

Graduates also note a lack of knowledge and skills in the "ability to negotiate" (48.6\%), but the greatest problem for representatives of this group is associated with a lack of "understanding of business processes of the enterprise and their relationships" (54.1\%). One third of graduates notes the lack of competence formation on the ability to present a product/service (Belenov et al., 2017).

Table 3. Competences insufficiently formed as a result of training

\begin{tabular}{|l|c|c|}
\hline Competences & $\begin{array}{l}\text { Students, \% from the } \\
\text { total group answers }\end{array}$ & $\begin{array}{l}\text { Graduates, \% from the } \\
\text { total group answers }\end{array}$ \\
\hline Computer/Internet skills & $17,20 \%$ & $8,10 \%$ \\
\hline Negotiation skills & $47,90 \%$ & $48,60 \%$ \\
\hline $\begin{array}{l}\text { Ability to competently conduct business } \\
\text { correspondence, make reports, speeches, other } \\
\text { documents }\end{array}$ & $45,40 \%$ & $37,80 \%$ \\
\hline
\end{tabular}




\begin{tabular}{|l|c|c|}
\hline $\begin{array}{l}\text { Understanding the business processes of the } \\
\text { enterprise and their relationships }\end{array}$ & $39,90 \%$ & $54,10 \%$ \\
\hline Ability to motivate others to work & $27,70 \%$ & $18,90 \%$ \\
\hline Ability to present the product, service & $25,20 \%$ & $32,40 \%$ \\
\hline Ability to establish contacts in the team & $25,20 \%$ & $13,50 \%$ \\
\hline $\begin{array}{l}\text { Ability to work in a team and achieve collective } \\
\text { goals }\end{array}$ & $23,90 \%$ & $16,20 \%$ \\
\hline Ability to defend your position correctly & $31,90 \%$ & $21,60 \%$ \\
\hline $\begin{array}{l}\text { Ability to work in specialized software products } \\
\text { (specify which ones) }\end{array}$ & $12,60 \%$ & $21,60 \%$ \\
\hline Practical skills in the specialty (please specify) & $31,50 \%$ & $21,60 \%$ \\
\hline
\end{tabular}

Source: Original material

2. Assessment of employers ' expectations for University graduates

The understanding of the advantages of young professionals differs significantly among the representatives of the target audiences (students, graduates and employers). Students are the least critical of their abilities; half of the representatives of this group believe that the reasons for hiring them are: readiness for further training, high level of motivation to work and professional activity, high-quality theoretical training and readiness to start a career from the grassroots $(55.3 \%, 54.9 \%$, $51.1 \%$ and $48.5 \%$, respectively).

The majority of graduates $(68.7 \%)$ believe that their main advantage is "readiness for further training"; other reasons that are the basis for preference by their employers are mentioned much less often.

The readiness of young professionals for further training is the most important reason for their employment for employers (79.3\%), who also mark the "high level of motivation to work and professional activity" as the feature of University graduates $(65.5 \%)$. It should be noted that the assessment of the level of motivation of graduates to professional activity is not perceived by employers unambiguously. On the one hand, more than a third of the representatives of this group call this reason as a motive for employment of graduates. On the other hand, when assessing the reasons for refusing to hire young professionals, one third of employers also note a low level of motivation of graduates to professional activity.

To implement a more detailed analysis of the needs of the market for graduates of higher educational institutions, determining a set of required competences for success in the professional field, a survey of employers with in-depth interview method was conducted (Belenov et al., 2017). A detailed discussion of the most demanded competences by the representatives of the enterprises has allowed to generate the following list: understanding business processes and manufacturing processes, working in a team to achieve common goals, ability to build contacts, negotiating skills, discipline, effective use of time, stress, work planning, identifying priorities, thoroughness and accuracy in the execution of tasks when working under pressure, responsibility and independence, the ability to calculate the consequences of the actions taken, learning, initiative, systematic thinking, the ability to see how the change of the element will affect the entire system as a whole. According to employers, the high level of development of these competences for graduates is the 
basis of their competitiveness in the labor market and the main prerequisite for a successful career promotion.

In-depth interviews revealed the reason for the applicants' employment refusal. Employers stressed that the main one is the insufficient level of professionalism and qualifications identified during the testing process, which is certainly the result of a certain inconsistency in professional and educational standards associated with differences in terminology and conceptual variations.

Overcoming inconsistencies and the formation of a unified approach is of great importance, because in the long term this tool (PS) will be an intermediary between the system of labor training and its use in the labor market, as it is a multifunctional normative document that provides requirements:

- for the content and quality of labor within a specific type (area) of professional activity;

- for the conditions of employment;

- for the level of qualification of the employee;

- for professional education and training necessary to meet this qualification (Belenov

O.N., Morozova V.N., Shilova I.V., 2016).

Professional standards are relevant not only for the employer. They serve as the basis for the formation of state educational standards and programs at all levels of professional education. Within the framework of the close interaction model between the business community and universities, it is necessary to create competence maps for the specialties most in demand in the regional labor market, in accordance with which educational programs should be developed.

The issues of communication between professional and educational standards are relevant for representatives of the labor market, which requires a model of professional education, developing under the influence of its requests and focused on the training of qualified workers who meet the needs of employers. Training of graduates who meet the requirements of the labor market and have the necessary competences involves the development of a standardized toolkit, which would allow to adequately assess the level of the graduate on the basis of objective criteria.

\section{Discussion}

For the systematic implementation of educational and innovative tasks and determining the most adequate prospects for the development of educational activities, it is necessary to track the changes in the quality of education by means of monitoring. The quality assessment system is based on the use of various evaluation mechanisms, including external and internal procedures for evaluating the learning process and its results, as well as procedures for receiving feedback from representatives of the target groups from the higher education institution (students and graduates, teachers and administrative staff of universities, employer organizations cooperating with universities, other groups of society cooperating with universities).

Based on the analysis of the most popular models for assessing the effectiveness of educational services, it is proposed to identify three main parts, the components of which are evaluated with varying degrees of involvement by parties interested in the activities of the center, i.e. representatives of target groups (Manual for Establishment of Centres for Competence and Employability Development, 2018):

1. The formation of input parameters for the study, which includes formulation and classification of goals and objectives based on the identification of training needs and development, including skills that must be formed during the training; identifying 
opportunities and resources, teaching methods and assessment criteria learning outcomes, development of techniques for estimation.

2. The contents and the learning process that involves the assessment of the training program main stages, techniques used, level and quality of teachers, proposed targets and verification/test conditions in which the educational process, finding out how efficient is the process of new competences formation.

3. Learning outcomes, evaluation of results in comparison with planned goals and objectives, changes in the behavior of students as a result of training, learning how the acquired knowledge and skills are applied in practice.

Within each component it is necessary to define blocks intended for evaluation by representatives of certain target audiences. To ensure the multi-criteria assessment of competences formed in higher education institutions, both quantitative and qualitative indicators should be used. A specific assessment tool in each case is selected individually; the indicator of efficiency orientation in an integral form can be calculated by averaging the scores for each educational program. In general this method is shown in the Figure 1.

Figure 1. Quality evaluation of educational services, results and training of University graduates.

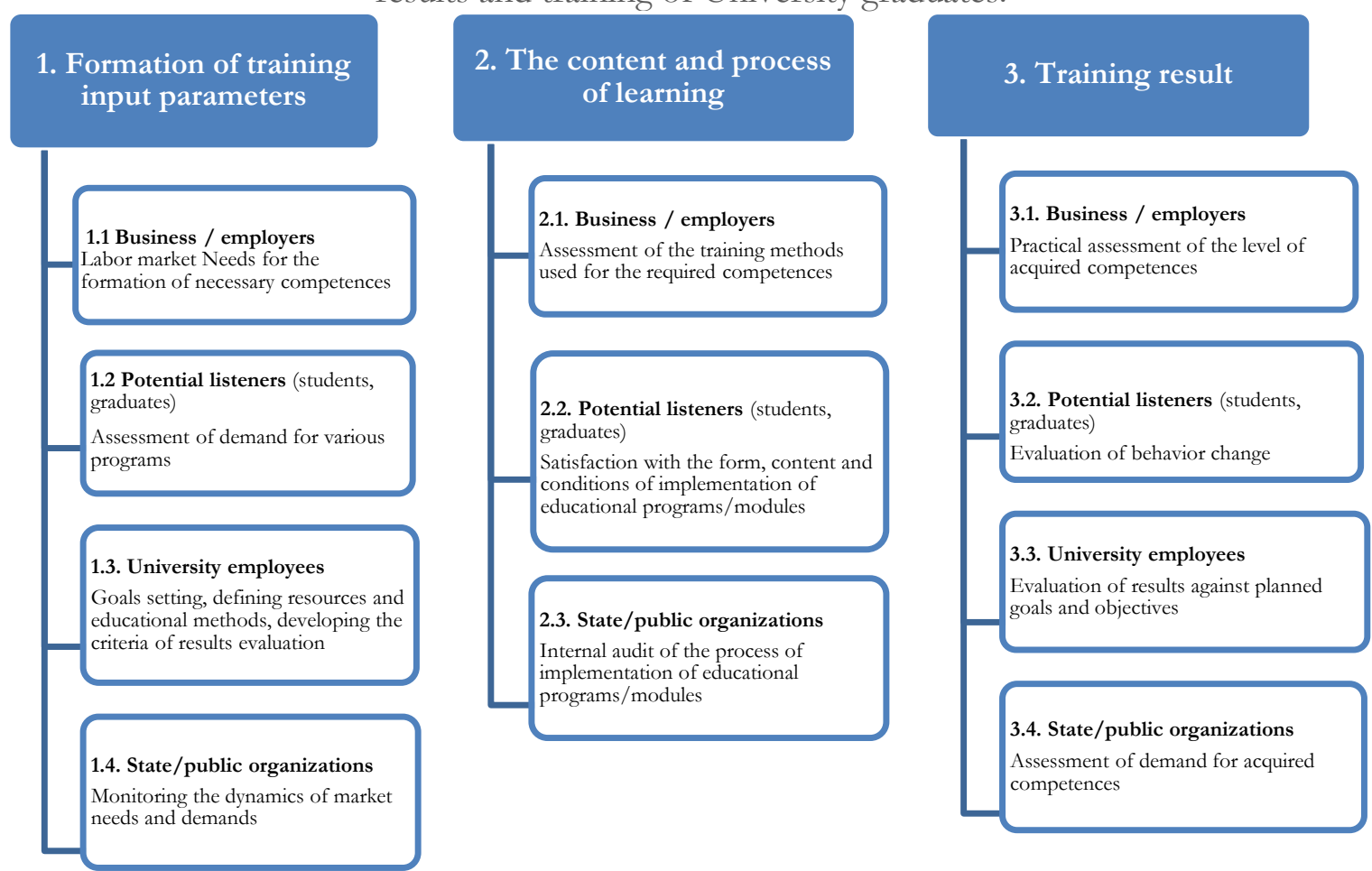

Source: Original material

The involvement of business in the educational environment provokes active modernization of educational process. Employers have the opportunity to formulate accessible and understandable requirements for the competence of the future specialist.

The role of the University, in turn, is to prepare students for working life and to provide them with the knowledge, skills and competences they need to obtain and secure a decent job, to make progress in the workplace, and to overcome the challenges posed by changes in technology and 
labor market conditions. Among others, the task of the University is to stimulate information exchange between the educational and business communities, create a system of measures aimed at expanding the background of students, their awareness of the need for continuous (lifelong) education as a major factor in career development. The key elements are the values that determine the education system in the innovative economy: the culture of search, renewal, use of a wide range of educational technologies and resources, focus on continuous improvement of key and professional competences.

However, the University cannot cover the full range of competences required by the labor market today; besides, this list is constantly expanding. Dynamic changes in the labor market, caused by the development of information technologies, lead to the fact that universities offer educational programs that do not meet the latest trends. Training centers and courses tend to be narrowly focused on training specialists to work with one particular technology, without providing fundamental education that would give potential professionals the opportunity to develop themselves and retrain quickly. One of the ways to solve this problem can be competence centers created on the basis of universities.

In order to increase the employability of the university graduates there was a Center for Competence and Employability Development (CCED) created in Voronezh State University as one of the effective tools to develop the soft skills necessary for future successful employment and career promotion. Universal competences, such as innovative thinking, responsibility, ability to search and process information, analytical thinking, ability to express own ideas, etc. are of high demand in Voronezh region. It was also discovered that the number of vacancies in such professions as manager, consultant, agent and sales representative significantly exceeds the number of unemployed, which significantly increases the chances of employment in these areas providing that the necessary skills are mastered as required by employers (Boldyrikhin A.A., Shilova I.V., 2018).

The creation of VSU CCED was approved and selected for financial support by the Erasmus+ Program "University Potential Development". Implementation period of the project is from 15.10.2015 to 14.10.2018. The project is aimed at creation of CCEDs that deliver professional consultations for education of bachelor and master students in terms of competence-based approach in education and that deal directly with the problems of employment. The creation of these centers is based on the absence of tailor-made programs and projects in the universities of Russia and Kazakhstan that would foster the employment of graduates and build up the dialogue between employers and institutions of higher education. As it becomes clear from the facts mentioned above, educating the graduates who would be able to successfully work and develop in the environment of rapidly changing requirements, is one of priority tasks for the universities. In order to achieve this important goal, formation of key competences during the study period is a necessary precondition for the graduates to correspond to the requirements of modern labor market. It is also important to note that professional higher education does not manage to change its structure in full accordance with changes in demand in the labor market and there is also a great demand for programs of additional training in the field of effective sales, copywriting, state procurement and Internet marketing [5].

The work of CCED is therefore focused on finding the ways to include a series of additional competences into the study programs that would increase the employability of graduates and would also assist to development of their personal potentials.

The results of CCED work have proved that there is a significant demand for consulting services and educational activities in the area of additional education on the basis of regional labor market 
requirements. It also made possible the adaptation of graduates to the labor market by developing universal and professional competences, also increasing their employability and helping companies and enterprises to find the desired specialists. The VSU CCED also helps to develop links and interaction between HEI and the labor market in order to implement the competence-based model of education with regard to the modern preferences of employers.

\section{REFERENCES}

Belenov O.N., Shilova I.V. (2017). What competences of university graduates are demanded in regional labour market. Proceedings of Voronezh State University. Series: Economics and Management, 1, 57-63. (in Russ).

Belenov O.N., Morozova V.N., Shilova I.V. (2016). Problems of formation of uniform criteria for assessing the quality of graduates by representatives of the labour market and the education sector. Proceedings of Voronezh State University. Series: Economics and Management, 3, 65-72. (in Russ).

Bochkareva R. A. (2010). Variability of formation of competitive advantages by vocational training on a labour market. Retrieved from https://cyberleninka.ru/article/v/variativnostformirovaniya-konkurentnyh-preimuschestv-professionalnym-obrazovaniem-na-rynketruda (in Russ.).

Boldyrikhin A.A., Shilova I.V. (2018). Approaches to increase the employability of graduates on the regional labor market. Collection of articles of the international conference - Almaty: Narxoz University, 13-20.

Burke, J. (2005). Competency Based Education And Training. Routledge.

Blömeke, S. Zlatkin-Troitschanskaia, O., Kuhn, C., Fege, J. (2013). Modeling and Measuring Competences in Higher Education: Tasks and Challenges. Springer Science \& Business Media.

COMPLETE - Establishment of Centers for Competence and Employability Development. Retrieved from http://cced-complete.com.

Eremina A.V., Zoroastrova I.V., Suchkova E.O. (2015). Identification of key competences of universities graduates. Studia Humanitatis No. 4. Retrieved from https://cyberleninka.ru/article/v/(in Russ.).

Fletcher, S. (2000). Competence-based Assessment Techniques. Kogan Page Publishers.

Gaivoronskaya S.A., Shilova I.V. (2018). Determination of the demanded universal competences of university graduates by employers of Russia and Kazakhstan. Proceedings of Voronezh State University. Series: Problems of higher education, No. 3 (3), 156-136. (in Russ).

Hartig, J., Klieme, E., Leutner, D. (2008). Assessment of Competences in Educational Contexts. Hogrefe Publishing.

Key competences for a successful life and a well-functioning society (2003) D.S. Rychen and L.H. Salganik (eds.)

Kekkonen A.L, Sigova S.V. (2011). Foreign experience in forecasting professional competences demanded in the labor market. Retrieved from http://www.labourmarket.ru/i_confs/conf8/book/iconf8_book1.pdf17(in Russ.).

Lierow, M. (2007). Competence-Building und Internationalisierungserfolg: Theoretische und empirische Betrachtung deutscher Unternehmen. Springer-Verlag. 
Lindgren, A., Heikkinen, A. (2004). Social Competences in Vocational and Continuing Education. Peter Lang.

Manual for Establishment of Centres for Competence and Employability Development Retrieved from

http://euspace.vsu.ru/UserFiles/files/complete/cced/manual_cced_implementation_ru. pdf (in Russ).

Martens, R., Heene, A., Sanchez, R. (2008). Competence Building and Leveraging in Interorganizational Relations. Emerald Group Publishing

Mulder, M. (2016). Competence-based Vocational and Professional Education: Bridging the Worlds of Work and Education. Springer.

Sigova S.V., Serebryakov A.G., Luksha P.O. (2013). Creating the list of competences in demand: first russian experience. Lifelong education: xxi century. 1 (1(1). Retrieved from https://1121.petrsu.ru/journal/article.php?id=1946 (in Russ).

Winter, R. Maisch, M. (2005). Professional Competence And Higher Education: The ASSET Programme. Routledge

Zaeer E., Zavodchikov D. (2011). Identification of universal competences of graduates by employers. Higher education in Russia No. 11. Retrieved from https:/ / cyberleninka.ru/article/n/identifikatsiya-universalnyh-kompetentsiyvypusknikov-rabotodatelem. (in Russ.).

\section{ABOUT'THE AUTHORS}

Boldyrikhin A.A.: Voronezh State University, International Relations Department, Lecturer of Chair of World Economy and Global Economic Activity, Ph.D. in Political Sciences

Russia, Voronezh, tel. 8 (900) 9595173

Contact information: commando@inbox.ru

Irina Shilova: Voronezh State University, International Relations Department, Lecturer of Chair of World Economy and Global Economic Activity

Russia, Voronezh, tel. 8 (900) 9459557

Contact information: shilova.irina05@gmail.com 